\title{
Cytotaxonomy of Dipetalogaster maxima Uhler, 1894 (Hemiptera, Reduviidae, Triatominae)
}

\author{
K. C. Borsatto ${ }^{(D}$, K. C. C. Alevi ${ }^{b}$ (D), J. Oliveira ${ }^{*}$ (D) and M. T. V. Azeredo-Oliveira ${ }^{a}$ (D) \\ aLaboratório de Biologia Celular, Departamento de Biologia, Instituto de Biociências, Letras e Ciências Exatas - IBILCE, \\ Universidade Estadual Paulista "Júlio de Mesquita Filho" - UNESP, Rua Cristóvão Colombo, 2265, Jardim Nazareth, \\ CEP 15054-000, São José do Rio Preto, SP, Brasil \\ ${ }^{\text {b} L a b o r a t o ́ r i o ~ d e ~ P a r a s i t o l o g i a, ~ D e p a r t a m e n t o ~ d e ~ C i e ̂ n c i a s ~ B i o l o ́ g i c a s, ~ F a c u l d a d e ~ d e ~ C i e ̂ n c i a s ~ F a r m a c e ̂ u t i c a s ~-~ F C F A R, ~}$ \\ Universidade Estadual Paulista “Júlio de Mesquita Filho" - UNESP, Rodovia Araraquara-Jaú, Km 1, CEP 14801-902, \\ Araraquara, SP, Brasil \\ *e-mail: jdr.oliveira@hotmail.com
}

Received: June 19, 2018 - Accepted: October 31, 2018 - Distributed: May 31, 2020

(With 2 figures)

\begin{abstract}
The Triatomini tribe consists of ten genera and is regarded as one of the most important tribes from epidemiological point of view. The genus Dipetalogaster Usinger, 1939 is composed only by the species Dipetalogaster maxima Uhler, 1894. This triatomine is exclusive of the Mexico and is a potential vector for Chagas disease. Besides the epidemiological importance, the insects of the Triatominae subfamily are important biological models for cytogenetic studies. Therefore, in order to contribute to the knowledge on the reproductive biology and assist in citotaxonomy of D. maxima, this study aimed to describe spermatogenesis, as well as confirm the karyotype and heterochromatic patterns of this Mexican triatomine species. The seminiferous tubules were torn, fixed to a cover slip and underwent the cytogenetic technique of Lacto-acetic orcein and C-banding. Through the cytogenetics analysis of testicular material $D$. maxima it was possible to confirm the karyotype $(2 \mathrm{n}=22)$, describe the stages of spermatogenesis and characterize the heterochromatic pattern (restricted to sex chromosome Y) of the species. D. maxima showed the same arrangement of heterochromatin described for Triatoma lecticularia (Stål, 1859) (a species that occur in United States of American and Mexico and is phylogenetically related with D. maxima), highlighting the importance of this analysis as an optimization tool to explore phylogenetic correlations.
\end{abstract}

Keywords: cytogenetics, meiosis, Mexican triatomine.

\section{Citotaxonomia de Dipetalogaster maxima Uhler, 1894 (Hemiptera, Reduviidae, Triatominae)}

\section{Resumo}

A tribo Triatomini consiste em dez gêneros e é considerada uma das tribos mais importantes do ponto de vista epidemiológico. O gênero Dipetalogaster Usinger, 1939 é composto apenas pela espécie Dipetalogaster maxima Uhler, 1894. Este triatomíneo é exclusivo do México e é um vetor potencial da doença de Chagas. Além da importância epidemiológica, os insetos da subfamília Triatominae são importantes modelos biológicos para estudos citogenéticos. Portanto, a fim de contribuir para o conhecimento da biologia reprodutiva e complementar o conceito específico de D. maxima, este trabalho objetivou descrever a espermatogênese, bem como confirmar o padrão cariotípico e heterocromático desta espécie mexicana, com foco citotaxonômico. Os túbulos seminíferos foram dilacerados, fixados em uma lamínula e submetidos à técnica citogenética de Orceína lacto-acética e Bandamento-C. Por meio da análise citogenética do material testicular de D. maxima foi possível confirmar o cariótipo $(2 \mathrm{n}=22)$, descrever os estágios da espermatogênese e caracterizar o padrão heterocromático (restrito ao cromossomo Y sexual) da espécie. D. maxima apresentou o mesmo arranjo de heterocromatina descrito para Triatoma lecticularia (Stål, 1859) (espécie que ocorre no México e nos Estados Unidos da América, filogeneticamente relacionada com D. maxima), destacando a importância desta técnica como ferramenta para explorar correlações filogenéticas.

Palavras-chave: citogenética, meiose, triatomíneo Mexicano.

\section{Introduction}

The Triatominae subfamily consists of 153 species distributed in 19 genera and five tribes (Galvão, 2014; Oliveira and Alevi, 2017; Dorn et al., 2018; Oliveira et al., 2018), being all species considered as potential insect

vector of Chagas disease. The Triatomini tribe is one of the most important from an epidemiological point of view and brings together ten genera of triatomines (Galvão, 2014). 
The genus Dipetalogaster Usinger, 1939 is composed only by the species Dipetalogaster maxima (Uhler, 1894). This triatomine is exclusive to Mexico (Galvão et al., 2003) and is a potential vector of Chagas disease, because has been found infected by the protozoan Trypanosoma cruzi (Chagas, 1909), in natural environments (Jimenez et al., 2003) and occasionally in rural households and peripheral areas (Lent and Wygodzinsky, 1979; Estrada et al., 1995). Costa et al. (1986, 1987, 1992) performed bionomic studies and analyzed the population dynamics and the influence of diet on several factors such as rhythm and posture, egg viability, fertility curve, female mortality, resistance to fasting and biological cycle.

Besides the epidemiological importance, the triatomines are important biological models for cytogenetic studies, because they have some peculiarities, as holocentric chromosomes, diffuse kinetochores and inverted meiosis to the sex chromosomes (Ueshima, 1966). Ueshima (1966) first proposed the use of cytogenetic data as a tool in taxonomy (cytotaxonomy) of triatomines. Recently, cytogenetic analyzes have proved to be important tools for studying the taxonomy of these vectors, emphasizing karyosystematic (Alevi et al., 2012, 2015a, 2018), meiotic (Panzera et al., 1998; Mendonça et al., 2014; Alevi et al., 2014, 2016a), of the pattern of constitutive heterochromatin (Perez et al., 1992; Panzera et al., 2000, 2010; Alevi et al., 2015b), heterochromatin base pair composition (Bardella et al., 2016; Alevi et al., 2017) and of the distribution of Nucleolus Organizer Regions (NOR) studies (Panzera et al., 2012; Pita et al., 2013, 2016).

Therefore, in order to contribute to the knowledge on the reproductive biology and assist in cytotaxonomic of D. maxima, this study aimed to describe spermatogenesis, as well as confirm the karyotype and heterochromatic pattern of this Mexican triatomine species.

\section{Material and Methods}

In this study, two adult males of D. maxima (Figure 1A) were used [the specimens were classified as D. maxima according to Lent and Wygodzinsky (1979)]. They had been assigned by insectarium of the Laboratory of Triatomines and Chagas Disease Epidemiology at the René Rachou Research Center (CPqRR/FICRUZ), Minas Gerais, Brazil. The testicles (Figure 1B1) of adult males were removed and seminiferous tubules (Figure 1B2) were torn and fixed to a cover slip. They then underwent the cytogenetic technique of Lacto-acetic orcein (for analysis of karyotype and spermatogenesis) [De Vaio et al. (1985), with modifications according to Alevi et al. (2012)] and C-banding for analysis of heterochromatin pattern (Sumner, 1972) and were analyzed using a Jenaval light microscope (Zeiss) attached to a digital camera and an Axio Vision LE 4.8 image analyzer (Copyright 2006-2009 Carl Zeiss Imaging Solutions $\mathrm{Gmb} \mathrm{H}$ ). The images obtained were magnified by a factor of $1000 x$.

\section{Results and Discussion}

Through the analysis of stained testicular material of D. maxima with Lacto-acetic orcein, it was possible to confirm the karyotype (Figure 1C) and describe spermatogenesis of the species (Figure 2). Analysis of meiotic metaphase D. maxima allowed possible to confirm the karyotype $2 \mathrm{n}=22$ chromosomes $(20 \mathrm{~A}+\mathrm{XY})$ (Figure 1C), originally described by Ueshima (1966).

Although the diverse in number of chromosomes $(2 \mathrm{n}=21,22,23,24$ and 25) in the Triatomini (Ueshima, 1966; Alevi et al., 2018), the karyotype $2 \mathrm{n}=22$ is the most frequently described for that tribe (Ueshima, 1966; Alevi et al., 2015a). It is believed that this number of
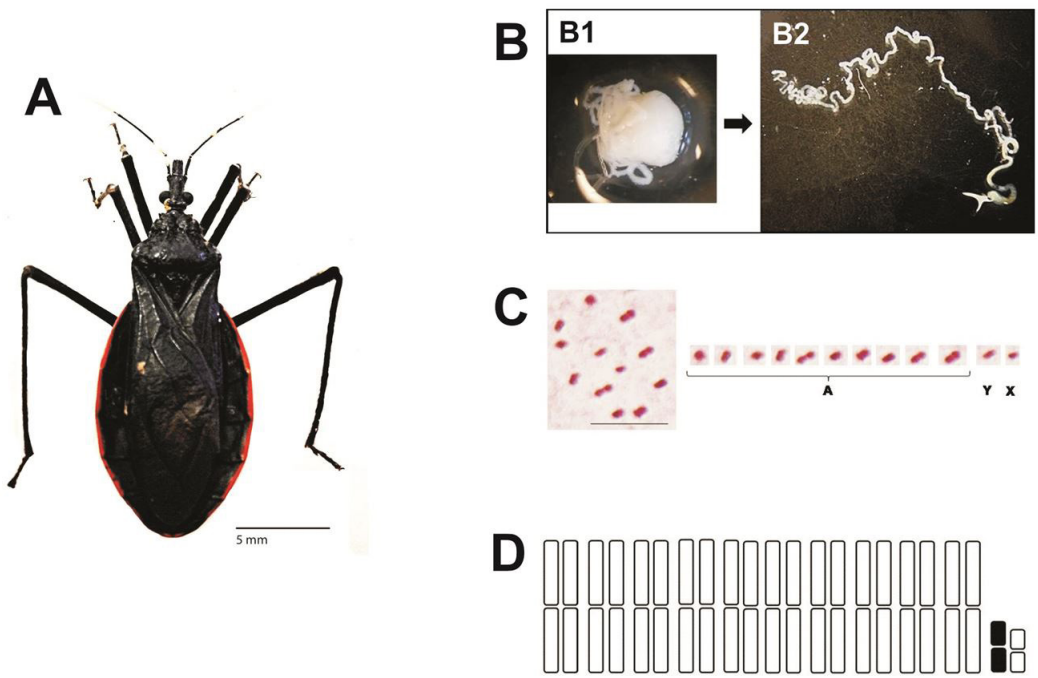

Figure 1. (A) Dipetalogaster maxima male; (B) Testicle (B1) and seminiferous tubule (B2) of D. maxima; (C) Karyotype of D. maxima $[2 \mathrm{n}=22(20 \mathrm{~A}+\mathrm{XY})]$. Bar: $10 \mu \mathrm{m}$. and (D) Ideogram representing the disposition of constitutive heterochromatin in D. maxima. Note the presence of heterochromatin restricted to sex chromosome Y. 

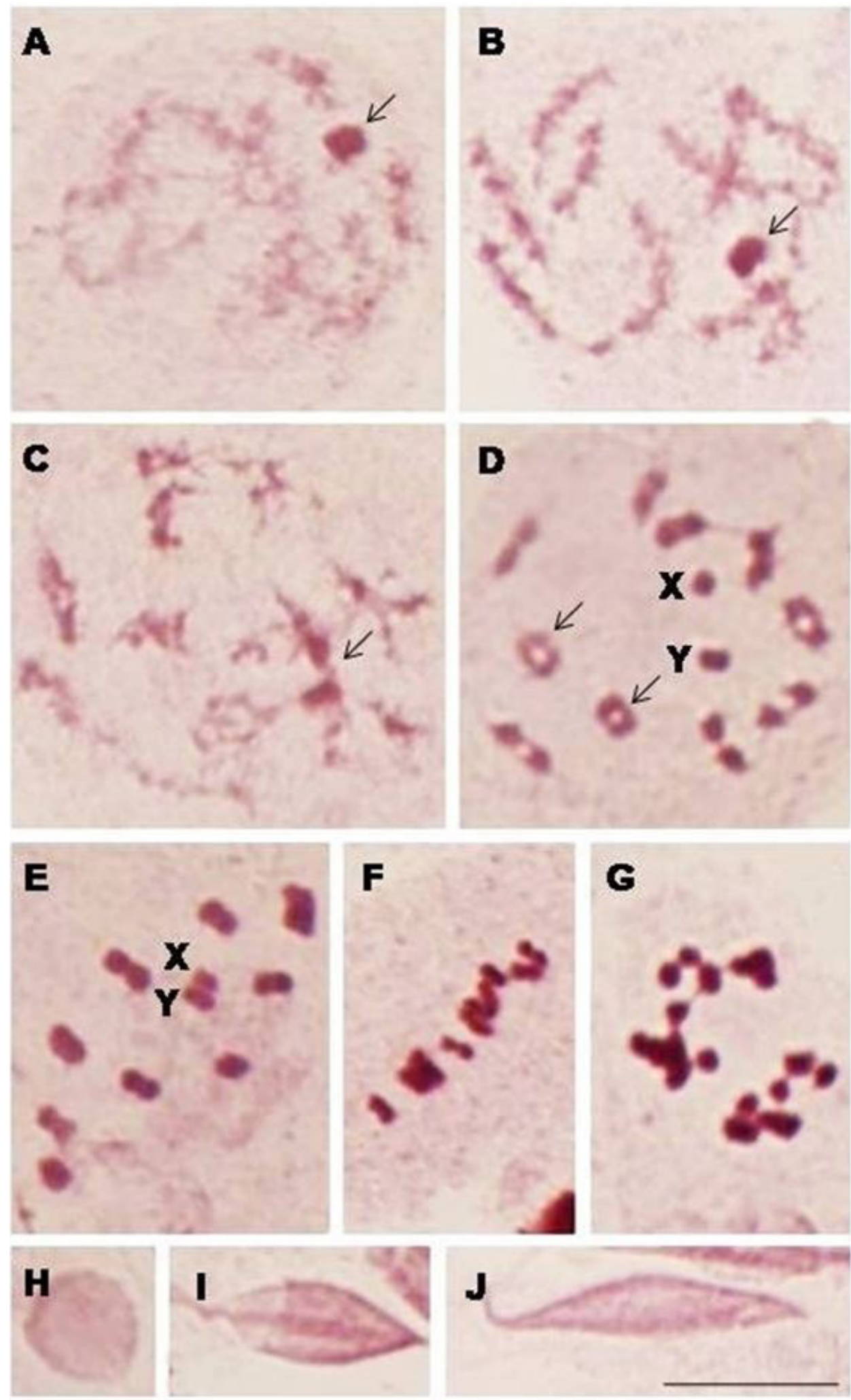

Figure 2. Spermatogenesis of D. maxima. (A-D) prophase. Note the compaction of chromatin (A-D). Presence of a heteropycnotic chromocenter (A-C, arrows), that differed in sex chromosomes X and Y. Also note the presence of chiasmus in diplotene (D-E, arrows); (E) metaphase in polar view; (F) metaphase in side view; (G) anaphase; (H-J) spermiogenesis. Bar: $10 \mu \mathrm{m}$. 
chromosomes is the same presented by the common ancestor of these blood-sucking insects (Ueshima, 1966).

During spermatogenesis (Figure 2), it was possible to describe the meiosis' stages (Figure 2A-G). The spermatogenesis consists of three main stages, namely spermatocytogenesis (mitosis), meiosis and spermiogenesis (Johnson et al., 1997). In triatomine, the spermatogenesis is considered cystic (Alevi et al., 2015 c). The prophases' analysis allow to observe compaction of chromatin (Figure 2A-D), the presence of a heteropycnotic chromocenter (Figure 2A-C, arrows) that differed in sex chromosomes $\mathrm{X}$ and $\mathrm{Y}$ and the presence of chiasma in cell's autosomes in diplotene (Figure 2D, arrows). Recently, the characterization of prophase of these vectors was considered an important cytotaxonomic tool for characterization of the Triatoma Laporte, 1832 genus of triatomines (Alevi et al., 2016b). The metaphases were observed in lateral (Figure 2E) and polar view (Figure 2F), confirming the karyotype and holocentric nature of chromosomes. Furthermore, it was also possible to observe the anaphase (Figure 2G) and characterize the elongation phases of spermatid during spermiogenesis (Figure 2H-J).

Through the analysis of stained slides by C-banding technique, was observed that D. maxima has constitutive heterochromatin restricted only to the Y sex chromosome, as illustrated by the ideogram (Figure 1D). Our results confirm the ones of Pita et al. (2014) which presents the Y sex chromosome of D. maxima as heterochromatic and marked by GUISH probes to repetitive sequences in the genome. D. maxima proved to be phylogenetically close to T. lecticularia (Stål, 1859) and Paratriatoma hirsuta Barber, 1938 (Justi et al., 2014). Although the heterochromatic pattern of $P$. hirsuta has not been characterized, T. lecticularia also presents karyotype $2 \mathrm{n}=22$ (Ueshima, 1966) and heterochromatin restricted to the Y sex chromosome (Panzera et al., 1998), demonstrating that the cytogenetic analyzes can be a tool to explore phylogenetic correlations.

Therefore, this paper describes spermatogenesis of D. maxima, confirmed the species' karyotype $(2 \mathrm{n}=22)$ and corroborated the phylogenetic relationship of D.maxima and T. lecticularia.

\section{Acknowledgements}

This study was supported by the Fundação de Apoio à Pesquisa e Extensão e São José do Rio Preto (FAPERP) (Process n ${ }^{\circ}$ 60/2015), Fundação de Amparo à Pesquisa do Estado de São Paulo (FAPESP) (Process n ${ }^{\circ}$ 2013/19764-0) and the Conselho Nacional de Desenvolvimento Científico e Tecnológico (CNPq). This study was financed in part by the Coordenação de Aperfeiçoamento de Pessoal de Nível Superior - Brasil (CAPES) - Finance Code 001. We appreciate the Dr. Lileia Diotaiuti for providing the insects for study.

\section{References}

ALEVI, K.C.C., MENDONÇA, P.P., PEREIRA, N.P., ROSA, J.A. and OLIVEIRA, M.T.V.A., 2012. Karyotype of Triatoma melanocephala Neiva and Pinto (1923): does this species fit in the Brasiliensis subcomplex? Infection, Genetics and Evolution, vol. 12, no. 8, pp. 1652-1653. http://dx.doi.org/10.1016/j. meegid.2012.06.011. PMid:22760157.

ALEVI, K.C.C., ROSA, J.A. and AZEREDO-OLIVEIRA, M.T.V., 2014. Cytotaxonomy of the Brasiliensis subcomplex and the Triatoma brasiliensis complex (Hemiptera: Reduviidae: Triatominae). Zootaxa, vol. 3838, no. 5, pp. 583-589. http://dx.doi. org/10.11646/zootaxa.3838.5.7. PMid:25081800.

ALEVI, K.C.C., BORSATTO, K.C., MOREIRA, F.F.F., JURBERG, J. and AZEREDO-OLIVEIRA, M.T.V., 2015a. Karyosystematics of Triatoma rubrofasciata (De Geer, 1773) (Hemiptera: Reduviidae: Triatominae). Zootaxa, vol. 3994, no. 3, pp. 433-438. http://dx.doi.org/10.11646/zootaxa.3994.3.7. PMid:26250283.

ALEVI, K.C.C., OLIVEIRA, J., MOREIRA, F.F.F., JURBERG, J., ROSA, J.A. and AZEREDO-OLIVEIRA, M.T.V., 2015b. Chromosomal characteristics and distribution of constitutive heterochromatin in the Matogrossensis and Rubrovaria subcomplexes. Infection, Genetics and Evolution, vol. 33, pp. 158-162. http:// dx.doi.org/10.1016/j.meegid.2015.04.024. PMid:25917494.

ALEVI, K.C.C., CASTRO, N.F.C., OLIVEIRA, J., ROSA, J.A. and AZEREDO-OLIVEIRA, M.T.V., 2015c. Cystic spermatogenesis in three species of the prolixus complex (Hemiptera: Triatominae). The Italian Journal of Zoology, vol. 82, pp. 172-178.

ALEVI, K.C.C., MOREIRA, F.F.F., JURBERG, J. and AZEREDOOLIVEIRA, M.T.V., 2016a. Description of diploid chromosome set of Triatoma pintodiasi (Hemiptera, Triatominae). Genetics and Molecular Research, vol. 15, no. 2, pp. 1-10. http://dx.doi. org/10.4238/gmr.15026343. PMid:27173222.

ALEVI, K.C.C., NASCIMENTO, K.C., MOREIRA, F.F.F., JURBERG, J. and AZEREDO-OLIVEIRA, M.T.V., 2016b. Cytogenetic characterisation of Triatoma rubrofasciata (De Geer) (Hemiptera, Triatominae) spermatocytes and its cytotaxonomic application. African Entomology, vol. 24, no. 1, pp. 257-260. http://dx.doi.org/10.4001/003.024.0257.

ALEVI, K.C.C., OLIVEIRA, J., AZEREDO-OLIVEIRA, M.T.V. and ROSA, J.A., 2017. Triatoma vitticeps subcomplex (Hemiptera, Reduviidae, Triatominae): a new grouping of Chagas disease vectors from South America. Parasites \& Vectors, vol. 10, no. 1, pp. 180. http://dx.doi.org/10.1186/s13071-017-2129-1. PMid:28407782.

ALEVI, K.C.C., OLIVEIRA, J., ROSA, J.A. and AZEREDOOLIVEIRA, M.T.V., 2018. Karyotype evolution of Chagas disease vectors (Hemiptera, Triatominae). The American Journal of Tropical Medicine and Hygiene, vol. 99, no. 1, pp. 87-89. http:// dx.doi.org/10.4269/ajtmh.17-0166. PMid:29785922.

BARDELLA, V.B., PITA, S., VANZELA, A.L.L., GALVÃO, C. and PANZERA, F., 2016. Heterochromatin base pair composition and diversification in holocentric chromosomes of kissing bugs (Hemiptera, Reduviidae). Memórias do Instituto Oswaldo Cruz, vol. 111, no. 10, pp. 614-624. http://dx.doi.org/10.1590/007402760160044. PMid:27759763.

COSTA, J., CUNHA, V. and JURBERG, J., 1992. Estudos Bionômicos de Dipetalogaster maximus (Uhler, 1894) (Hemiptera, 
Reduviidae, Triatominae) III. Dinâmica populacional. Memórias do Instituto Oswaldo Cruz, vol. 87, suppl. 1, pp. 73-80. http:// dx.doi.org/10.1590/S0074-02761992000500014. PMid:1343801.

COSTA, J., JURBERG, J. and ALMEIDA, J.R., 1986. Estudos bionômicos de Dipetalogaster maximus (Uhler, 1894) (Hemiptera, Reduviidae, Triatominae). Parte I: influência da dieta sobre: ritmo e postura, viabilidade dos ovos, curva de fertilidade e mortalidade das fêmeas. Memórias do Instituto Oswaldo Cruz, vol. 82, no. 1, pp. 365-380. http://dx.doi.org/10.1590/S0074-02761986000400003.

COSTA, J., JURBERG, J. and ALMEIDA, J.R., 1987. Estudos bionômicos de Dipetalogaster maximus (Uhler, 1894) (Hemiptera, Reduviidae, Triatominae). Parte II: influência da dieta sobre a resistência ao jejum e ciclo biológico. Memórias do Instituto Oswaldo Cruz, vol. 82, pp. 111-118. http://dx.doi.org/10.1590/ S0074-02761987000100018.

DE VAIO, E.S., GRUCCI, B., CASTAGNINO, A.M., FRANCA, M.E. and MARTÍNEZ, M.E., 1985. Meiotic differences between three triatomine species (Hemiptera:Reduviidae). Genetica, vol. 67, no. 3, pp. 185-191. http://dx.doi.org/10.1007/BF02424489.

DORN, P.L., JUSTI, S.A., DALE, C., STEVENS, L., GALVÃO, C., LIMA-CORDÓN, R. and MONROY, C., 2018. Description of Triatoma mopan sp. n. (Hemiptera, Reduviidae, Triatominae) from a cave in Belize. ZooKeys, vol. 775, pp. 69-95. http://dx.doi. org/10.3897/zookeys.775.22553. PMid:30057472.

ESTRADA, M., ARCHILA, O., PREZA, R. and VELASCO, O., 1995. Dipetalogaster maximus parasitada por Trypanosoma cruzi en área sub-urbana de la ciudad de la Paz. Baja California Sur: Departamento Estatal de Epidemiologia, Secretaria de Salud.

GALVÃO, C., 2014. Vetores da doença de chagas no Brasil. Curitiba: Sociedade Brasileira de Zoologia, 289 p. http://dx.doi. org/10.7476/9788598203096.

GAlVÃO, C., CARCAVAllo, R.U., ROCHA, D.S. and JURBERG, J., 2003. A checklist of the current valid species of the subfamily Triatominae Jeannel, 1919 (Hemiptera, Reduviidae) and their geographical distribution, with nomenclatural and taxonomic notes. Zootaxa, vol. 202, no. 1, pp. 1-36. http://dx.doi. org/10.11646/zootaxa.202.1.1.

JIMÉNEZ, M.L., LLINAS, J. and PALACIOS, C., 2003. Infection rates in Dipetalogaster maxima (Reduviidae: Triatominae) by Trypanosoma cruzi in Cape Region, Baja California Sur, Mexico. Journal of Medical Entomology, vol. 40, no. 1, pp. 18-21. http:// dx.doi.org/10.1603/0022-2585-40.1.18. PMid:12597648.

JOHNSON, L., BLANCHARD, T.L., VARNER, D.D. and SCRUTCHFIELD, W.L., 1997. Factors affecting spermatogenesis in the stallion. Theriogenology, vol. 48, no. 7, pp. 1199-1216. http:// dx.doi.org/10.1016/S0093-691X(97)00353-1. PMid:16728209.

JUSTI, S.A., RUSSO, C.A.M., MALLET, J.R.S., OBARA, M.T. and GALVÃO, C., 2014. Molecular phylogeny of Triatomini (Hemiptera: Reduviidae: Triatominae). Parasites \& Vectors, vol. 7, no. 1, pp. 149. http://dx.doi.org/10.1186/1756-3305-7-149. PMid:24685273.

LENT, H. and WYGODZINSKY, P., 1979. Revision of the Triatominae (Hemiptera: Reduviidae) and their significance as vector of Chagas's disease. Bulletin of the American Museum of Natural History, vol. 163, pp. 123-520.

MENDONÇA, V.J., ALEVI, K.C.C., MEDEIROS, L.M.O., NASCIMENTO, J.D., AZEREDO-OLIVEIRA, M.T.V. and ROSA, J.A., 2014. Cytogenetic and morphologic approaches of hybrids from experimental crosses between Triatoma lenti Sherlock \& Serafim, 1967 and T. sherlocki Papa et al., 2002 (Hemiptera: Reduviidae). Infection, Genetics and Evolution, vol. 26, pp. 123-131. http://dx.doi.org/10.1016/j.meegid.2014.05.015. PMid:24861813

OLIVEIRA, J. and ALEVI, K.C.C., 2017. Taxonomic status of Panstrongylus herreri Wygodzinsky, 1948 and the number of Chagas disease vectors. Revista da Sociedade Brasileira de Medicina Tropical, vol. 50, no. 3, pp. 434-435. http://dx.doi. org/10.1590/0037-8682-0125-2017. PMid:28700072.

OLIVEIRA, J., AYALA, J.M., JUSTI, S.A., ROSA, J.A. and GALVÃO, C., 2018. Description of a new species of Nesotriatoma Usinger, 1944 from Cuba and revalidation of synonymy between Nesotriatoma bruneri (Usinger, 1944) and N. flavida (Neiva, 1911) (Hemiptera, Reduviidae, Triatominae). Journal of Vector Ecology, vol. 43, no. 1, pp. 148-157. http://dx.doi.org/10.1111/ jvec.12294. PMid:29757512.

PANZERA, F., SCVORTZOFF, E., PEREZ, R., PANZERA, Y., HORNOS, S., CESTAU, R., NICOLINI, P., DELGADO, V., ALVAREZ, F., MAZZELLA, M., COSSIO, G., MARTINEZ, M. and SALVATELLA, R., 1998. Cytogenetics of Triatomines. In: R.U. CARCAVALLO, I. GALÍNDEZ-GIRÓN, J. JURBERG and H. LENT, eds. Atlas of Chagas disease vectors in the Americas. Rio de Janeiro: Fiocruz, pp. 621-664.

PANZERA, F., PÉREZ, R., NICOLINI, P., HORNOS, P., COSTA, J., BORGES, E., DIOTAIUTI, L. and SCHOFIELD, J., 2000. Chromosome homogeneity in populations of Triatoma brasiliensis Neiva 1911 (Hemiptera, Reduviidae, Triatominae). Cadernos de Saúde Pública, vol. 16, suppl. 2, pp. 83-88. http:// dx.doi.org/10.1590/S0102-311X2000000800009. PMid:11119323.

PANZERA, F., PÉREZ, R., PANZERA, Y., FERRANDIS, I., FERREIRO, M.J. and CALLEROS, L., 2010. Cytogenetics and genome evolution in the subfamily Triatominae (Hemiptera, Reduviidae). Cytogenetic and Genome Research, vol. 128, no. 1-3, pp. 77-87. http://dx.doi.org/10.1159/000298824. PMid:20407223.

PANZERA, Y., PITA, S., FERREIRO, M.J., FERRANDIS, I., LAGES, C., PÉREZ, R., SILVA, A.E., GUERRA, M. and PANZERA, F., 2012. High dynamics of rDNA cluster location in kissing bug holocentric chromosomes (Triatominae, Heteroptera). Cytogenetic and Genome Research, vol. 138, no. 1, pp. 56-67. http://dx.doi.org/10.1159/000341888. PMid:22907389.

PÉREZ, R., PANZERA, Y., SCAFIEZZO, S., MAZZELLA, M.C., PANZERA, F., DUJARDIN, J.P. and SCVORTZOFF, E., 1992. Cytogenetics as a tool for triatomine species distinction (Hemiptera-Reduviidae). Memórias do Instituto Oswaldo Cruz, vol. 87, no. 3, pp. 353-361. http://dx.doi.org/10.1590/S007402761992000300004 . PMid:1343644.

PITA, S., PANZERA, F., FERRANDIS, I., GALVÃO, C., GÓMEZ-PALACIO, A. and PANZERA, Y., 2013. Chromosomal divergence and evolutionary inferences in Rhodniini based on the chromosomal location of ribosomal genes. Memórias do Instituto Oswaldo Cruz, vol. 108, no. 3, pp. 376-382. http:// dx.doi.org/10.1590/S0074-02762013000300017. PMid:23778665.

PITA, S., PANZERA, F., SÁNCHEZ, A., PANZERA, Y., PALOMEQUE, T. and LORITE, P., 2014. Distribution and evolution of repeated sequences in genomes of Triatominae (Hemiptera-Reduviidae) inferred from genomic in situ hybridization. PLoS One, vol. 9, no. 12, pp. e114298. http://dx.doi.org/10.1371/ journal.pone.0114298. PMid:25478792. 
PITA, S., LORITE, P., NATTERO, J., GALVÃO, C., ALEVI, K.C.C., TEVES, S.C., AZEREDO-OLIVEIRA, M.T.V. and PANZERA, F., 2016. New arrangements on several species subcomplexes of Triatoma genus based on the chromosomal position of ribosomal genes (Hemiptera - Triatominae). Infection, Genetics and Evolution, vol. 43, pp. 225-231. http://dx.doi. org/10.1016/j.meegid.2016.05.028. PMid:27245153.
SUMNER, A.T., 1972. A simple technique for demonstrating centromeric heterochromatin. Experimental Cell Research, vol. 75, no. 1, pp. 304-306. http://dx.doi.org/10.1016/00144827(72)90558-7. PMid:4117921.

UESHIMA, N., 1966. Cytotaxonomy of the Triatominae (Reduviidae, Hemiptera). Chromosoma, vol. 18, no. 1, pp. 97122. http://dx.doi.org/10.1007/BF00326447. 